\title{
Night in the Capitalist, Cold War City: Noir and the Cultural Politics of Darkness
}

\section{Bryan D. Palmer}

The Cold War reaches across the international history of the twentieth century, a disfigurement that leaves a frozen burn scorching the politics and culture of diverse moments, scarring east and west in ways different but reciprocal. More than a brief interlude associated with the post-World War II campaigns of Senator Joseph McCarthy, the anti-communism central to politics in the twentieth century is a pivotal practice of containment that begins with the making of the first revolutionary workers' state in the Soviet Union in 1917 and continues well after the implosion of actually existing socialism at the end of the 1980s. ${ }^{1}$ The ugliness of this two-sided Cold War conditioned and pressured Stalinist atrocity as well as the evils of disingenuous democratic display, the Russian purge show trails of the late $1930 \mathrm{~s}^{2}$ having their seemingly benign counterpart in the House Un-American Activities Committee (HUAC) meetings where the dubious practice of naming names turned the United States into an informer society, in which people traded the honor of political convictions for the material securities of status and positions. ${ }^{3}$

Bodies thus litter the political landscape. The extermination of the entire human apparatus of original Bolshevism in the degeneration of Stalinized Soviet life, not to mention the vast death march in the countryside of induced famine or the Gulag of political and cultural repression, wrote finis to the liberatory hopes many associated with workers' revolution and the accomplishments of 1917. What followed in the United States was of course less chillingly terroristic, but the visible tip of an iceberg of denunciation with deadly consequences reaches from the Rosenbergs to lesser-known figures, such as the sensitive Canadian scholar of Japanese feudalism and career diplomat, E.H. Norman, who finally committed suicide in Cairo after being hounded by McCarthyism's watchdogs for almost a decade. ${ }^{4}$ In the process few areas of cultural life remained untouched and as thousands were blacklisted from government circles, teaching jobs, journalist posts, Hollywood, and the arts community, ${ }^{5}$ the Cold War at its mid-century zenith exercised a pernicious impact on avant-garde movements from abstract expressionism to modern jazz. ${ }^{6}$

This article takes one such cultural form, noir, as a representational medium articulating a cultural politics of darkness, and locates it within Cold War America. Drawing out the night as both a time and a place within which noir's narratives were ideally situated, as well as a metaphor usefully symbolic in noir's oppositional scripts of estrangement and alienation, this essay attempts a broad introduction to the genre, albeit one situated at the interface of discrete aspects of style and social content. It then closes with a particular reading of 


\section{Left History 5.2}

one classic noir text, the Jules Dassin-directed film, Night and the City (1950), concluding with a brief acknowledgement of the different politico-aesthetics of contemporary, late capitalist, noir productions.

Noir, both fiction and film, is one of those quintessentially modernist American cultural developments whose essence has proven, for generations of critics, notoriously difficult to locate with definitional precision. ${ }^{7}$ As Raymond Borde and Etienne Chaumeton suggested in their original assessment of film noir, Panorama du Film Noir Américain (1955), it was the darkness at the heart of this new genre that lent it a certain coherence, and one that coincided, interestingly, with a set of techniques, from off-centred 'shots' and eerie lighting to filming on night location, many of which can be located in a materialized stylistics of wartime production overdetermined by budget constraints that limited the small producers as well as affecting the large studios. Noir is thus defined, in content foremost, but also in a congruent aesthetics, as disorientation. A fundamental break with literary and cinematic convention, in which well-understood moral reference points had long been universally presented as statements of inherently timeless social values, such as good, beauty, and honor, noir's core was its refusal to reproduce the parables of propriety. Instead, noir introduced the destabilization of ambivalence and the challenging referant of reversal: good and evil were cojoined to the point of being indistinguishable; classical heroes and heroines were displaced by protagonists mired in the depths of depravity; animating narratives of chaos and confusion were motivations presented in their most base and disturbing light. Stylistically juxtaposing the bizzare and fantastic with a relentless sequence of 'realist' snapshots, moreover, noir created an atmosphere of the ultra-normal periodically ruptured by the weird, the violent, and the disturbing, often shot 'close-up' or framed tightly, lending it the tenor, again, of an off-putting imbalance, claustrophobic in its containments. Audiences thus experienced noir, especially in its cinematic variants, as anguish and insecurity, a genre of apprehension. ${ }^{8}$

The background to this complex emergence of noir's forms, which included its prose as well as Hollywood variants, is thus multifaceted. Recent feminist commentary has often addressed noir as something of a male gaze, a fantasy of repression in which the desires and determinations of independent women are subordinated and brought back into the familialist fold of nurturing conventions. Such an interpretation certainly has resonance with historical circumstances, especially pronounced in the United States, where the fluidity of gender relations was quite pronounced in the decades preceeding noir's evolving place in popular culture. From the post-World War I 1920s to the economically-pressured malaise of the Great Depression into the malestrom of the 1940 s, sexuality and male-female relations shifted gears dramatically, conditioning a volatility in gender relations that no doubt fed into the possibility that one dimension of anxiety addressed by noir would inevitably be the sustaining of male authority. There is no doubt much to this reading, although there is 
contention within critical feminist circles about the dissidence of a noir genre that congealed desire and destruction in ways that often provided an erosion of patriarchy's codes and conformities. ${ }^{9}$

If gender scripted noir's moment of emergence, so too did class. A part of the genre's origins lay in the depressingly stark 1930s realization that even the seemingly protected middle classes now faced the distorting prospects of economic insecurity, downward mobility, and the consequent psychological turmoil. It was the translation of this experience of socio-economic unease into the dark artistic conventions of the 1940s that allowed for noir's aesthetic purchase on an ambiguous generation that witnessed the capacity of boom to reverse itself into bust, sounding the deathknell of complacent security and proclaiming an age of alienation. In Edward Hopper's oils, this representational engagement with estrangement found a uniquely American expression, in which the shadowed virtual photo-realism of the archetypally noirish Nighthawks (1942) drew on themes the artist had explored earlier, pushing his 1920 s articulations of anomie in more unambiguously alienated directions. Images of automats, drug stories, and burlesque houses, all crafted by Hopper in the late 1920s, gave way to later post-1940 productions of office scenes, often shadowed in the night. ${ }^{10}$ In these paintings, Hopper cast the commerce of the day in the noirish juxtaposition of work time's supposed end, achieving an effect not unlike the David Mamet play and James Foley-directed 1992 film, Glengarry Glen Ross, in which darkness provides a context for capitalism's seemiest competitive manipulations and psychological damage to expose themselves. Hopper's Summer Evening (1947) typifies noir's rough-edged destiny of despair, the lighted porch framed by the night providing a venue pregnant with sensuality, conspiracy, and a hard-boiled cynicism drifting inevitably toward an end of no good. ${ }^{11}$

This hybrid representational evolution can be located in the lead-ups to and subsequent shadows of the Cold War. ${ }^{12}$ Noir as a genre was born in the subterfuges of the 'popular front,' where the programatic suppression of revolutionary intention through integration into the mainstreams of bourgeois order orchestrated a politics of accommodation always ostensibly turning on clandestine articulations of oppositional theory and practice. ${ }^{13}$ Left-leaning Hollywood auteurs made the most of this 'cultural front' and gravitated to the ambivalences of noir instinctually, seeing in it "a shrewdly oblique strategy for an otherwise subversive realism." ${ }^{14} \mathrm{~A}$ case in point was the quintessential "popular front' writer, Vera Caspary, whose route from Jewish middle-class Chicago to Hollywood took her through two-and-a-half years in the Communist Party in New York and Connecticut, and involvement in the whirlwind activism of the 'cultural front' of the 1940s. In her autobiography, The Secrets of Grown-Ups (1979), Caspary recalled engaging with the politics of the Anti-Nazi League, the League Against War and Fascism, and the League of American Writers. She taught writing classes in order to earn money to 
bring refugee authors to America. "For the Left," she remembered, "these were fruitful years. ... Almost every night there were fund-raising parties, benefits and concerts. There was a steady infux of new people coming to work in the studios - actors, writers, directors from New York, refugees from Europe." Casparay's thriller Laura (1942) became a noir classic, albeit one, under Otto Preminger's direction, that exemplified the subordination of the femme fatale to the male voice-over and reduced women's experience, unlike Casparay's text, to a superficial surface resistant to analysis. ${ }^{15}$ In the period of the 'popular front,' then, noir attracted dissident authors and film makers, and was even to a certain extent crafted by them: in its oblique capacities to scaffold a critique of capitalism on the disintegrating rungs of conventional moral authority, noir was a voice raised against the sanctimoniousness of the socio-economic context from within its particular confinements. This was not Marxist, pace Michael Denning's appreciation of the 'cultural front,' as much as it was comfortably in alignment with the ambivalences of the Communist Party's relationship with capitalism and the American state.

The disintegrating political certainties of the 1940s, in which the nation's moral core was a unified opposition to fascism, found themselves cut adrift in the realignments of post-World War II anti-communism. With the 'popular front' dismantled and the posture of reaction hardening dangerously day-byday, it was even more impossible to make cinema Marxist at mid-century. But noir's formalistic darkness continued to allow the depiction of capitalism's unsavory undercurrents, spinning out the moral tales of an underground city where the productions of honest toil always lose out to the quick fixes of corruption and speculative vice, where the délcassé rich and the gangster predator rule an economy of easy money and its purchase on the good life. ${ }^{16}$ In noir, the attractions of the night always supercede those of the day and, when given the choice, noir anti-heroes inevitably choose betrayals and thefts, even murder, over honest toil and hard labor. That they cannot win at capitalism's game is what no doubt made noir an attractive vehicle for Hollywood's progressives, among them the writers John Huston and Malvin Wald and the directors George E. Diskant and Jules Dassin, ${ }^{17}$ but this message of doomed defeat also had its attractions in the Cold War climate of the reactionary 1950s, where the compensations of the hard-boiled style renegotiated masculinity in an epoch of proletarian defeat and domestication, both at the point of production and in the ideological arena. ${ }^{18}$

In its most successful cinematic expressions, noir negotiated these shifting political contours in a unique fusion of heavy-handed German expressionism, orchestrated by expatriate directors such as Fritz Lang, ${ }^{19}$ Otto Preminger, ${ }^{20}$ Billy Wilder, Anatole Litvak, and Max Steiner, with the hard-boiled American prose stylistics of Dashiel Hammet, ${ }^{21}$ whose The Maltese Falcon, first published in 1930, marks the generally-accepted debut of film noir in the 1941 Humphrey Bogart-Mary Astor production. ${ }^{22}$ On California's Sunshine Coast, 
where heavy industry was weaker than in other geographic sectors, where old money was judged in decades not centuries, where rural America was physically quite close but socially so phenomenally distant, and where the hustling boosterism of Hollywood lent the economic climate a fantasy-like hyperreality that seemed not all that far removed from the actualities of a political economy always on the verge of running away from itself, the potential for cultural and political fermentation was, as Mike Davis has suggested, truly bizarre. ${ }^{23}$ "It is traumatic for an individual to lose a set of beliefs," writes the film noir critic Carl Richardson, whose exploration of the impact of the 1930s suggests that, "For a world-wide coterie of intellectuals and artists, it is a dark, frustrating process. It is a film noir on a large scale." 24

From out of the depths of the Great Depression came a series of real-life blows, their artistic renditions beginning with James M. Cain's The Postman Always Rings Twice (1934), ${ }^{25}$ Horace McCoy's They Shoot Horses Don't They (1935) ${ }^{26}$ and Nathanael West's The Day of the Locusts (1939), stories of descent, debilitation, debauchery, and despair that seemed to replicate a part of the argument of Lewis Corey's/Louis Fraina's unsettling analysis, Crisis of the Middle Class (1935). Captured artistically in Philip Evergood's painting, Dance Marathon (1934), this "proletarian grotesque," in the words of Michael Denning, pushed images of play into the representational realm of its opposite, "the dance marathon" becoming "an allegory of an American capitalism in which endless, repetitive amusement and entertainment is oppressive, consuming the dreams of its youth," whose lives are squandered in economic depression, turning the pleasures of pastimes such as dance into the most routinized "wage labor."27 In conjunction with Raymond Chandler's reconstruction of the world of the Los Angeles rich, eyeballed by the tough guy private dick, Phillip Marlowe, and always tarnished by a moral darkness that could be opened up to the light only by the vernacular of the people, such texts turned the page toward noir's urban futilities. ${ }^{28}$ Two years before he died Chandler wrote to his London solicitor, "I have lived my life on the edge of nothing." 29

If the origins of this accommodation lay in the economic malaise of the 1930s, the final reconciliation was one of a seemingly psychological real politique, in which recognition of what was possible in the give-and-take of capitalism's ensembles of power was adapted to, rather than challenged, with particular psychic costs. ${ }^{30}$ The astute Afro-Caribbean Marxist, C.L.R. James, grasped the dualism of this cultural negotiation, appreciating its subtle subversions as well as its incarcerating incorporations. Noir institutionalized traditionalist values of individualism, and James located the attraction of the genre in the rugged American need to stand alone. The heroic fatalism of noir's protagonists was an almost universal self-reliance, apart from all structures of constituted authority, and most emphatically distanced from law and propriety: "He had to be an ordinary guy - one who went out and did the job himself." In the context of closed frontiers and obvious barriers to the mythic dreams of 
American acquisitive individualism, undeniable in the post-Depression epoch of capitalistism's powerful monopolistic grasp on material power, noir sustained "a sense of active living, and in the bloodshed, the violence, the freedom from restraint to allow pent-up feelings free play," James discerned a possible release of "the bitterness, hate, fear, and sadism" which he saw simmering below the discontented surface of social relations. ${ }^{31}$ But if James saw in this narrative of cultural appropriation and understanding the potential of resistance, there was much to overcome to mobilize its possibilities, not the least of noir's cultivations being the construction of a dark imagary that, in its predictable postures, erases the living realities of day-to-day oppression in the distorted shadows of night's always unfullfilled dreams, sliding inevitably into the sinister hole of nightmarish fears from which the only exit appears a fantasy of forgetfulness. ${ }^{32}$

Noir's exploration of such themes often took on purely economic dimensions, albeit in ways that could blur into sexual pathologies, where the spent currency of erotic fulfillment generally had a crassly materialistic character. To be sure, there was the possibility of diversity always present in noir's unfolding dramas. In Chester Himes's If He Hollers Let Him Go (1945), for instance, Hollywood's racism found a bitter chronicler, one that would be born again in the soft-peddling 1980s and 1990s with Walter Mosley's Easy Rawlins mysteries, Devil in a Blue Dress, A Red Death, and White Butterfly, but this racial commentary was a rare intervention in the white plots of noir's acquisitive individualism. ${ }^{33}$ Nevertheless, regardless of the route to noir's endnote, its culde-sac conclusion was universally marked by its darkened realism.

Chandler noted in 1950, the Cold War breaking all around him, "We still have dreams, but we know that most of them will come to nothing. And we also most fortunately know that it really doesn't matter." With the Hollywood Ten battling the blacklist, Chandler could declare, "This is not an age of reason or tolerance, but in Hollywood you don't learn to be a hero. You learn to be expedient - or you get to hell out." 34 There wasn't much, after all, beyond the big sleep: "What did it matter where you lay once you were dead? In a dirty sump or in a marble tower on top of a high hill? You were dead, you were sleeping the big sleep, you were not bothered by things like that." ${ }^{35}$ The message, again, would reappear in the twisted reversals of the staccato-like prose and sparse aesthetics of the Los Angeles novels of James Ellroy, a nightmareinduced 1980s/early 1990s noir quartet — The Black Dahalia (1987), The Big Nowhere (1988), L.A. Confidential (1990), and White Jazz (1993) - that had its origins in the author's mother's unresolved murder. ${ }^{36}$

Noir proved such a reservoir for the avant-garde aspirations of the 1940s and 1950s precisely because it seemed the perfect accommodation: one that embraced alienation, tried to overcome it, reproduced the evil it aimed to transcend, and returned to the ever-troubling heart of darkness at the core of human existence. The contradictory impulse of the genre nurtured a profound moral 
ambivalence, a conspiracy of silencing anguish conscious in its intention to produce emotional insecurity: noir was nothing less, in the words of its original interpreters, than "that state of tension instilled in the spectator when the pyschological reference points are removed. The aim of film noir was to create a specific alienation." 37 One of the great character actors of film noir, Elisha Cook, Jr., whose credits included 13 major motion pictures, starting with The Maltese Falcon and continuing through Phantom Lady (1944), The Big Sleep (1946), Born to Kill (1947), The Killing (1956), and Baby Face Nelson (1957), grasped this intuitively when he described his roles: "I played rats, pimps, informers, hopheads, and communists," a veritable catalogue listing of undesirables. Noir typecast, not the admirable hero, but the fall-guy anti-hero. ${ }^{38}$

This dark moral reversal was as much an articulation of form as it was of substance. Moods, rather than plots, dominate noir, and as a cinematic genre noir was built around frustrations and fears, claustrophobias and psychic chaos, an anxiety-ridden context of paranoia all too often embedded in a troubling experience of defeat. Film noir's human centerpieces were constructions of lonely obsessions, narrowed to the point that they suffocate those who cannot effectively wrestle their own demons into the backgrounds where they belong, allowing 'healthy' perspectives of human relationships and purposes to come into the foreground. Against idealized conceptions of families, communities, and commitments, noir presented a dark, foreboding culture of shocking individualism, an endlessly alienated pursuit of illusive material gratifications that short-circuited the American Dream, pushing it in the direction of an always-on-the-verge-of-imploding nightmare. In the plot lines of noir everything good is permeated with the polluting evils of greed and lust, excesses of the estranged self that manage to corrupt human vulnerability and force it toward its ugliest poles of (dis)attraction. Stylistic devices, from close-ups of anguished faces to distorted lighting, mirror reflections, silouetted figures, haunting flashbacks, outlandish camera angles or shadowed walls and twisted profiles, contribute to the making of skewed perspectives that are the formal presentation of a message of something seriously awry in the human condition, ${ }^{39}$ and that had their material origins in both the scarcities and social perspectives of World War II (which constricted the possibilities of shooting, lighting, and editing). ${ }^{40}$

Above all else, noir elevated the night to a dark moment of human estrangement, the time and place of unstable environment in which unattainable strivings produce the undoing of men and women, their every act 'shot' in orchestrated 'night-on-night' scenes that broke with cinematic tradition to present the oppositional possibilities of day and night. In The Night Has a Thousand Eyes (1947), Edward G. Robinson, a tormented psychic with the power to predict death, lives beneath the oppression of the stars, which fatally oversee his adventures. "I had become a reverse zombie, the world was dead and I was living," Robinson explains. ${ }^{41}$ Visual motifs thus translated into exis- 


\section{Left History 5.2}

tential comment, as the dark boundaries of existence constrict inward in a tightening knot of noir's capacity to effect a material transfiguration, in which the physicality of a scene becomes the tortured content of a soul. ${ }^{42}$ "The Streets were dark with something more than night," declares Edward G. Robinson in The Woman in the Window (1945), while Mark Stevens proclaims in The Dark Corner (1946), "I'm backed up in a dark corner and I don't know who's hitting me." In both scenes the the spatial and shadowed context of enclosure move, in conjunction with dialogue and the cinematic process of framing, from one of place to one of psyche, not unlike the HUAC settings in which the bright light of anti-communism shone illuminatingly through speeches of pathetic recantation. After having resisted the McCarthyite witchhunt for two years, for instance, Lee J. Cobb found himself penniless and out of work, his wife institutionalized as an alcoholic. He finally broke, testified before HUAC, and informed on his colleagues by naming twenty individuals as 'known' communists and identifying others as left-wingers within the Actors Equity Guild. Now able to secure employment, Cobb sufferred a massive coronary (his hospital bills being covered by Frank Sinatra) before landing the entirely appropriate role of the compliant Johnny Friendly in On the Waterfront (1954). Cobb's final statement to HUAC was a pusillanimously-pitched justification of his sad denouement, one in which he thanked the modern-day Inquisition for allowing him "the privilege of setting the record straight ... further strengthening ... our Government and its efforts at home and abroad." 43 Film noir at least spared its audience such pathetic blandishments. All that the noir anti-hero could generally accomplish, against such powerful transfiguration, was a temporary stay of personal solitude, a quiet, desperate retreat from the confusion that relentlessly sinks optimism in the rough waves of impending darkness, a final futile statement or gesture.$^{44}$ Cobb would have been better to have settled for as minimalist much.

To analytically isolate a classic film noir presentation is perhaps an impossibility, so diverse were the Hollywood offerings in this genre. Between The Maltese Falcon (1941) and Orson Welles' Touch of Evil (1958) literally hundreds of noir films were made, encompassing a range of formalized types from the socially critical commentary of The Naked City (1948) and Nightmare Alley (1947) through the gangster film, The Racket (1951) or The Ashphalt Jungle (1950), to the generalized noir theme of fatalism and demoralization attendent on greed and the adventure of quests for pathological acquisitions, be they material, psychological or sexual. In the latter category can be placed many of the private eye adaptations of classic Hammett and Chandler fiction, as well as Humphrey Bogart films such as High Sierra (1941), Key Largo (1948), Dead Reckoning (1947), and In a Lonely Place (1950). Ironically enough the least successful variants of noir were those consciously right-wing statements, such as the dour melodrama, Ride the Pink Horse (1947), and explicit Cold War productions that attempted to actually frontally address anti- 
communism. Films such as I Was A Communist for the F.B.I. (1951) pale in comparision, aesthetically and intellectually, when placed beside the materialized eroticization of estrangement evident in Double Indemnity (1944), The Postman Always Rings Twice (1946), or Clash by Night (1952). Yet as perhaps one of the classic noir statements, the blacklisted director-in-exile Jules Dassin's Night and the City (1950) reveals, the imagery and representational force of noir was never all that far removed from the Cold War's stifling presence. ${ }^{45}$

Dassin was one of the premier Hollywood noir directors. Between 19411946 he directed eight shorts and features, including Nazi Agent (1942) and the light comedy, The Affairs of Martha (1942), in which a servant authors a scandalous book about her employers. Dassin's creative genius burst forth in 19471948, however, with three critically-acclaimed credits, Brute Force, Thieves' Highway, and The Naked City, some of which drew the ire of the FBI. While the latter had the stark presentation of a docudrama, the former films marked Dassin as one of Hollywood's more socially conscious artists, unrelenting in his condemnation of the meaninglessness and everyday violence of routinized life, a champion of the mythic, proletarian conflict ubiquitous in the maelstrom of bourgeois order. When his noir counterpart, imprisoned UkrainianCanadian Edward Dmytryk of the infamous 'Hollywood Ten' sought the favor of HUAC and 'purged' himself before the Committee by identifying Dassin as a supposed communist, the latter, against whom there was little tangible 'evidence' save for Dmytryk's self-interested testimony, found himself persecuted and blacklisted. Dmytryk, the only member of the 'Hollywood Ten' to recant in this way went on to direct The Sniper (1952), a thinly-veiled defence of political repression that elided deviance and dissidence in the justification of incarcerating sex offenders in mental hospitals (it was the time of Francis Farmer, after all), ${ }^{46}$ and the highly-acclaimed The Caine Mutiny (1954), which carried the authoritarian message that even incompetent leaders deserve the regard of those serving under them, whose allegiance must be total and unwavering ${ }^{47}$ Rather than dignify HUAC and its project, Dassin left the United States and set himself up in England. Out of work for five years, his first film in exile was Night and the City, a cinematic tour through the themes of noir shot against a background of darkest London, a Dickensian underworld of con men, hustlers, petty thieves, street urchins, dance hall girls, beggars, and bookies, a labyrinth of stairwells, bridges, construction sites, hideaways, constricted spaces, and parodied dangers. ${ }^{48}$

Inhabiting this terrain of the street and its foggy and smokey alleyways, through which he is almost always on the run, is the American expatriate on the proverbial make, Harry Fabian, played by the noir icon, Richard Widmark. Fabian is forever in search of his rightful score, a man on the perpetual edge, for whom his long-suffering, golden-hearted girlfriend, Mary Bristol, provides a ready source of petty cash. But as Harry works himself into the limelight of 


\section{Left History 5.2}

"being somebody," of actually "having it all," the stakes are raised to the point where nobody, and certainly not Mary, can pull Harry out of his fated demise. Harry, described by a romantic rival whose genuine decency (and somewhat homosexualized persona) eliminates him from Mary's slightest consideration, as "an artist without an art," succumbs in the end to a betrayl of art, paying the ultimate price. Cynically befriending Gregorius, the innocent if patriarchal figurehead of European Greco-Roman wrestling and the aged, disenchanted father of the unsavory, immigrant, criminal 'boss' of London's emerging postwar commercialized wrestling scene, the ruthlessly powerful Kristo, Harry Fabian uses his capacities as a con man to hustle his way into potentially rivalling the underworld emperor, angering in the process his nightclub-owner employer, the obese Nosseross, whose faithless wife Helen barters her husband's festishistic and pathetic love in a crudely symbiotic sexualized/materialized hit on Harry meant to secure her a difficult-to-obtain liquor licence. For a while, Harry's capacity to con virtually everyone around him appears to be paying dividends. With Gregorius in his corner, his ventures bankrolled by Nosseross, and his ploys playing out, Fabian's name is about to head the marquee of London wrestling's biggest coup, an epic, theatrical battle between classical, artistic Greco-Roman wrestling and the psychopathology of 'the fight game' as a presentation of freaks, epitomized in the personage of Kristo's star performer, the subhuman 'Strangler.'

Yet Harry's bonanza, unfolding as it seems to be, eventually unravels as his con predictably oversteps itself and his markers are called in by those, such as Nosseross and Kristo, who hold the decisively powerful cards. In the end Harry is reduced to what he has always been, a man on the run (he complains in his last hour that he has forever been running, from welfare agents, his father, the police, while Mary warned him at the beginning of the film that he had to stop running someday if he ever wanted to be 'normal,' to stop sweating), an exile in his own adopted city (not unlike Dassin himself), a figure with a price on his head that few of his fellow hustlers can resist (again, not unlike Dassin in the world of Hollywood's HUAC). London becomes a literal city of the damned, its night scenes ones of Harry scrambling over war bombed rubble, seeking futile refuge against the damp-darkened walls of the Thames or in the refuse of London's wharf rats. With the bridge aswarm with Kristo's ready soldiers, Harry faces a dark dawn as a man whose time has finally run out. Without a word of politics, Dassin creates a commentary on the world of the Cold War, in which exile, frustration, and defeat at the hands of powerful forces of evil dogs those "who just want to be somebody," a line of pathos uttered by Fabian that predated Marlon Brando's famous On the Waterfront statement by three years.

Visually the film is a condemnation of the cynicism and despair of the corruptions of the post-war capitalist marketplace. In Beggar's Lane, where one of Harry's cronies outfits the commercial panhandlers with false limbs and 
other props that make them a more viable conduit for cash, the pit-like darkness captures capitalism's incarceration of the working class, while the seediness of exchange relations offers a stark metaphor for the crass hucksterism of metropolitan capital. In the subterranean nightclub lair of the Silver Fox, an aptly-named den of wily duplicity, a grotesque Nosseross strokes his cash like a caricature of the grasping, bloated exploiter, his life confined to the office from which he looks appropriately down upon the noctural theatre of his crass bilking of a male clientele that makes itself a ready sucker for every costly pseudo-sexual come-on. The underground Emperor, Kristo, flanked by his lawyer and bodyguard, is the only figure who looms over London's skyline, marking his time and eventually exacting his revenge, the living embodiment that not only does crime pay, but that it ultimately calls all of the shots. In the background, the smaller predators circle the ever-present human prey. Money rules this universe of greed and corruption, a signifier of worth that appears always out of nowhere, emerging from transactions behind the scenes, manufactured from wheelings and dealings always bargained falsely, money that passes hands in thick elastic-wrapped packages, money that is stroked sensually by those devoid of human eroticism, money that talks the language of empty promise but can never actually buy anything of worth. Between a man and his money, one of the characters soliliquizes, nothing can come. Harry's obsessional pursuit of this money and the supposed fame it will secure him is the tragic flaw in a life of anguished movement that takes Harry only in the circular spiral of his inevitable free-fall into a final, friendless hell. Mary tells him in the end that he could have done anything: with brains, ambition, and hard work Harry is a heroic figure, but his lack of art insures that he will always pursue "the wrong things." In the London night Harry Fabian is eventually reduced to just such a "wrong thing": everything is for sale as a car speeds through the enclosed blocks of Harry's increasingly claustrophobic world, announcing to all and sundry the thousand pound price on Harry Fabian's head. The man who had managed to 'get it all' also signed his own death warrant by pushing the game of self realization too far. The rules of class place and social station, bent to the point of snapping by those at the top of the small, social pyramid of London's subculture of the night street, are only so flexible. For the Harry Fabians they provide just enough give to rebound back in death. Harry at least goes to this end with some grace, doing what he can to secure Kristo's blood money to his lover Mary, who, alone in the London of the night, stands by the man who has offered her only the cold comfort of his own insatiable ambitions, and a willingness to do virtually anything to realize them. ${ }^{49}$

Night and the City is thus an ongoing social commentary on the labyrinth of post-war capitalism and its Cold War politics of repressive containment, a challenging exploration all the more effective precisely because it seems far removed from the subject of its caustic critique. Symbolized at its highest level in Dassin's film as commercially-promoted wrestling, capitalism is insightful- 
ly constructed as a staged event, a noir preface to postmodern theory's grasp of the critical importance of spectacle in a decaying order in which the marketing of images outpaces the production of goods, of which there is no sign whatever in the rotting darkness of Night and the City, where everything for sale is a recycled subterfuge, a crafted fraud. Barthes' understanding of Parisian wrestling in roughly the same period suggests the significance of this spectacle and its relationship to noir as a genre. "The virtue of all-in wrestling is that it is the spectacle of excess," states Barthes in his opening analytic line; and, indeed, noir and its Cold War subjects are also about excess. Wrestling, like noir, "abandons itself to the primary virtue of the spectacle, which is to abolish all motives and all consequences," a process the Cold War codified. Noir anti-heroes are not unlike Barthes' wrestlers, nor are they all that different than those who purged themselves before HUAC: "the function of the wrestler is not to win; it is to go exactly through the motions which are expected of him. ... a man who is down is exaggeratedly so, and completely fills the eyes of the spectators with the intolerable spectacle of his own powerlessness." This can be marketed and sold as spectacle precisely because the genuineness of its content is beside the point: "What the public wants is the image of passion, not passion itself," an axiom applicable to Night and the City's central locale, the Silver Fox nightclub, a staged sensuality that, in all of its darkly designed disingenuousness, poisons the capacity for passion between Nosseross, or No Eros, and his calculatingly cold wife Helen. Noir and wrestling elevate the 'bastard' to the standard of humanity, as perhaps does capitalism. And to visualize such a 'bastard' aesthetically is noir's contribution, a culture of darkness entirely congruent with post-war capitalism's politics of Cold War night. "Some fights," comments Barthes, "among the most successful kind, are crowned by a final charivari, a sort of unrestrained fantasia where the rules, the laws of the genre, the referee's censuring and the limits of the ring are abolished, swept away by a triumphant disorder ... [a] return to the orgy of evil which alone makes good wrestling." 50 Noir's final frames could hardly be better described, nor capitalism's trajectory more aptly characterized.

What Mike Davis calls the "transformational grammar"51 of noir was thus capable of sustaining an acute artistic paradox within the constricting sociopolitical climate of the Cold War; noir's oppositional success was to play within conventional boundaries, but to caricature those boundaries mercilessly. Not only did noir, as Davis suggests, shift the language of charming boosterism and optimistic ambition away from its veneer of social niceties and into the dark recesses of its sinister counterparts of greed and the materially-induced manipulations (and worse) of hucksterism, it managed to represent themes literally outlawed in the moment of the Cold War freeze on social commentary. Anticommunism had so suppressed the possibility of cinematic depictions of working-class life that noir's unsubtle exploitation of this equally unsubtle exercise of censorship merely followed the trajectory of exclusion by exagger- 
ating the inversion of powerlessness, creating a dark resoir of humanity whose marginality pushed past that of an organized proletariat into the shadowy isolations of rootless 'society,' where cab drivers, dance hall girls, war veterans, boxers, private detectives, and criminals symbolize the 'have nots' stripped even of the collectivity of wage-earning jobs and the associational authorities of unions, communities, and political activities. As capitalism was reified in the post-World War II years as a saviour of humankind, the acquisitive individualism of the marketplace was darkened in noir's depicition of 'bosses' as emperors of the underworld, czars of their particularly disreputable enterprises of the night: the clubs, bars, rings, and cul-de-sacs where cash always changes hands in the most sordid of ways. If race, a pivotal social divide in post-World War II America, was also exorcised by the Cold War demons as too contentiously hot a political issue to handle without yet again introducing the potential of dissidence, noir's pressured whiteness managed to racialize otherness in the contorted savagery of a set of dangerously powerful freaks and geeks, ${ }^{52}$ usually used crassly by powerfully evil figures who can be undone by the simple humanity of their cretinous but ultimately innocent dupes. Even in noir's unashamedly misogynistic presentation of the inner tensions of gendered greed, the mere presence of the femme fatale was potentially powerfully subversive of sexual stereotyping, not only because she was a persistent frustration of male desire, but because she defied a patriarchal culture's limiting subordinations of female place and tightening definitions of womanly need.$^{53}$ As Janey Place has suggested, noir women usually disrupt the conventional narrative in the disorienting presentation of an unrepressed female sexuality, often combined with a rapacious materialism, a rare cinematic articulation of women's strengths in the realms of eros and accumulation. ${ }^{54}$ The only winner in Night and the City is the old hag of the Silver Fox nightclub, shunned by beauty but rewarded by the nightclub owner beast, who wills her his property in a final act of revenge directed against his unfaithful and contemptuously repulsed wife.

Noir thus rewrote the script of Cold War culture. If its darkness submerged themes of social protest in the long night of alienation, noir refused to collapse the entirety of critical representation's repertoire into the soft, fleshy monotones of prettified propogandizing for an American Way of Life. Films such as Nicholas Ray's They Live By Night (1947) battled the censors' demands to downplay social criticism, eliminate reference to war profiteering, and tone down depictions of post-war affluence as propelled by consumer hucksters such as used car dealers who were the thieves of a new, crudely acquisitive, social order ${ }^{55}$ Noir's elevation of the night and the searches for self realization that unfolded within its darkness offered coded counterpoints to the jaded and jaundiced conventionalities of the time, centred in the mythologies of idealized families and communities. Noir presented an introspective, always fatally flawed, flight from such conformist confinement, an escape pushed by scarred 
backgrounds and unwholesome needs, but one at least cognizant of human suffering and abuse and incapable of papering over the larger social ills that it was the Cold War's ultimate purpose to deny and obfuscate.

This open-ended set of noir possibilities has proven particularly durable and, after a momentary decline in the context of a mid-to-late 1950s Hollywood demand for a more prettified pontification of the bourgeoisie's many virtues, noir has proven a rare modernist genre that manages to both keep a proletarian kernel and the anticommunist background of its formative moment alive, as in Gordon Demarco's 1980s Trotskyist-leaning detective, Riley Kovachs, who battles Stalinist union corruption, racism, and McCarthyism. ${ }^{56}$ The genre assimilated other stylistics, to be sure, but it cloned its spectacular rebirth in the 1970s and 1980s, where the neo-noir productions Chinatown (1974), Taxi Driver (1976) and Blue Velvet (1987) were but a cinematic preface to an onslaught of resurgent noir in the $1990 \mathrm{~s},{ }^{57}$ extending from the big screen to the televised popularity of noirish series such as Miami Vice and Homicide, which had been preceeded by such late 1950s productions as Peter Gunn, perhaps the most mass-directed introduction of the subtle subversions of jazz to a white mainstream audience. ${ }^{58}$ Ideally suited to the rebirth of the 'savage art' of the now depoliticized anarcho-communist-populist, Jim Thompson, whose dark explorations of the underworld of the 1930s and 1940s produced some of the most volatile fiction of the noir genre, moving well past Chandler and Hammett, the cinematic reconfiguration of noir under late capitalism commenced with two 1990 Thompson remakes, The Grifters and After Dark, My Sweet ${ }^{59}$ Soon followed by the innovations of Quentin Tarentino and others, most of 1990 s neo-noir had a decidedly destructive conception of the 'family values' that had been pressured into the politics of mainstream culture at the time: Reservoir Dogs (1992); Red Rock West (1992); Pulp Fiction (1994); The Last Seduction (1994). ${ }^{60}$ Throughout this explosion of dark cinema, the gendered nature of greed, always present in traditional noir's inability to transcend a bifurcation of woman into evil, predatory temptress or saintly, victimized adornment, flows easily into late twentieth century constructions of masculine womanhood, every bit as capable of seizing whatever main chance presents itself as debased manhood. ${ }^{61}$

With noir's rebirth in the late twentieth century, however, its production was less pressured by the political containments of the 1940s and 1950s, and its sexualized possibility expanded considerably from the tighter censorship restrictions of earlier decades, governed by Will Hays, the prudish Production Code Administration, and the Catholic Church's Legion of Decency. ${ }^{62}$ Transgressive sexuality, from the subthemes of incest that figure forcefully in Chinatown and The Grifters to the bending content of homosexuality in The Last Seduction, fuses with the overarching theme of noir, money and its disfiguring capacities. If there is a 'hard-boiled' equivalent to Chandler and Hammett in the $1980 \mathrm{~s}$ and $1990 \mathrm{~s}$, where the proliferation of assembly-line 
'mystery' writers such as James Lee Burke, Lawrence Block, and their female counterpart, Sue Grafton, have bleached noir of much of its darkness, smoothing its rough edges in a filing down of the genre's open antagonisms, it is Andrew Vachss, whose private detective, Burke, is a product of child abuse and the ugliness of the state reformatory system, an eroticized avenger. A crusader untroubled by the moralities of Marlowe or Sam Spade, Burke is a mercenary of the night, a depoliticized defender of innocent children, the strong silent type gone outlaw. His turf is the city of darkness, the night markets where predators prowl for victims and where the rough justice of noir can still manage a late twentieth-century scaffolding, albeit one crafted somewhat differently than traditional noir's recognizable politics of representation. ${ }^{63}$

This fin-de-siècle rescripting of noir's nature, in which the Cold War is displaced, leaves the contemporary 1990s genre twisting in the winds of a peculiar 'end of history' culturalist climate, where nihilism, chaos and sensationalism blow with gusto. ${ }^{64}$ But the subtle craft of noir's original imagery has, in the process, been jettisoned, yet another casualty of the truly 'big sleep' of capitalism's current ascendancy.

\footnotetext{
${ }^{1}$ This position, in which the Cold War is extended back in time, as well as perhaps forward into the future, seems to me congruent with positions adopted by William Appleman Williams. See, for example, The Tragedy of American Diplomacy (New York 1962); Paul M. Buhle and Edward Rice-Maximin, William Appleman Williams: The Tragedy of Empire (London 1995). On McCarthy see David M. Oshinsky, A Conspiracy So Immense: The World of Joe McCarthy (New York 1983); Richard M. Fried, Nightmare in Red: The McCarthy Era in Perspective (New York 1990).

${ }^{2}$ See for instance The Case of Leon Trotsky: Report of hearings on the Charges Made Against Him in the Moscow Trials By the Preliminary Commission of Inquiry (New York 1937).

${ }^{3}$ This process is explored in the case of the Hollywood blacklist in Victor S. Navasky, Naming Names (New York 1980); Patrick McGilligan and Paul Buhle, eds., Tender Comrades: A Backstory of the Hollywood Blacklist (New York 1997), as well as in the more wide-ranging statement, Larry Ceplair and Steven Englund, The Inquisition in Hollywood: Politics in the Film Community, 1930-1960 (Berkeley 1983); and for a particular figure see Lester Cole, Hollywood Red: The Autobiography of Lester Cole (Palo Alta, Ca. 1981). Note as well Sally Belfrage, Un-American Activities: A Memoir of the Fifties (New York 1994).

${ }^{4}$ On the Rosenbergs see the old statement John Wexley, The Judgement of Julius and Ethel Rosenberg (New York 1955), and the more acclimated Ronald Radosh and Joyce Milton, The Rosenberg File: A Search for Truth (New York 1984). E.H. Norman's case remains controversial. See Peyton V. Lyon, "The Loyalties of E. Herbert Norman," Labour/Le Travail, 28 (Fall 1991), 219-259; James Barros, No Sense of Evil: Espionage and the Case of Herbert Norman (Toronto 1986); Roger W. Bowen, Innocence is Not Enough: The Life and Death of Herbert Norman (Vancouver 1986).

${ }^{5}$ Note David Caute, The Great Fear: The Anti-Communist Purge Under Truman and
} 


\section{Left History 5.2}

Eisenhower (New York 1979); Len Scher, The Un-Canadians: True Stories of the Blacklist Era (Toronto 1992).

${ }^{6}$ Consider Frank Kofsky, "Black Music: Cold War 'Secret Weapon," in Kofsky, Black Nationalism and the Revolution in Music (New York 1970), 109-122; Serge Guilbault, How New York Stole the Idea of Modern Art: Abstract Expressionism, Freedom, and the Cold War (Chicago 1983). For a general cultural history of the Cold War see Tom Engelhardt, The End of Victory Culture: Cold War America and the Disillusioning of a Generation (New York 1995), while the context of the cultural front deployed by Michael Denning in The Cultural Front: The Laboring of American Culture in the Twentieth Century (London 1996) provides a sense of the 'progressive' opposition's immediate historical background.

${ }^{7}$ On problems of definition and the range of writings, related especially to film noir, see Alain Silver, "Introduction," in Alain Silver and James Ursini, eds., Film Noir Reader (New York 1996), 3-15.

${ }^{8}$ I have drawn on the useful abbreviated statement in Raymond Borde and Etienne Chaumeton, "Towards a Definition of Film Noir," in Silver and Ursini, eds., Film Noir, 17-25.

9See, Janey Place, "Women in Film Noir," in E. Ann Kaplan, ed., Women and Film Noir (London 1978), 50, on female repression and male power, and the extended engagement with this position in Elizabeth Cowie, "Film Noir and Women," in Joan Copjec, ed., Shades of Noir: A Reader (London 1993), 121-166.

${ }^{10}$ For other comment on noir and the office see Fredric Jameson, "The Synoptic Chandler," in Copjec, ed., Shades of Noir, 33-56.

${ }^{11}$ Hopper's works, and biographical and analytic perspectives, are found in: Gail Levin, Edward Hopper: An Intimate Biography (New York 1995); Deborah Lyons and Adam D. Weinberg, Edward Hopper and the American Imagination (New York 1995); Wieland Schmied, Edward Hopper: Portraits of America (New York and Munich 1995); Gail Levin, Edward Hopper: The Art and the Artist (New York 1980); Gail Levin, "Edward Hopper: The Influence of Theatre and Film," Arts Magazine, 55 (October 1980), 123-127; Erika Doss, "Edward Hopper, Nighthawks, and Film Noir," Postcript: Essays in Film and the Humanities, 2 (Winter 1983), 14-36.

${ }^{12}$ On contextualization see Charles Higham and Joel Greenberg, Hollywood in the Forties (New York 1968) and Dana Polan, Power and Paranoia: History, Narrative and the American Cinema, 1940-1950 (New York 1986).

${ }^{13}$ It goes without saying, then, that I reject the uncritical readings of the 'popular front' that have captivated much of the political and cultural historiography of this period, as evident in Denning, The Cultural Front and Maurice Isserman, Which Side Were You On? The American Communist Party During the Second World War (Middletown, Ct. 1982). For an alternative reading, more in line with my views, see Michael Goldfield, "Recent Historiography of the Communist Party USA," in Mike Davis, et al., eds., The Year Left: An American Socialist Yearbook, 1985 (London 1985), 315-358.

${ }^{14}$ Mike Davis, City of Quartz: Excavating the Future in Los Angeles (New York 1992), 41.

${ }^{15}$ On Casparay see Denning, Cultural Front, 144-145, 228; Vera Casparay, The Secrets of Grown-Ups (New York 1979). For a feminist critique of Laura see Karen Hollinger, "Film Noir, Voice-over, and the Femme Fatale," in Silver and Ursini, eds., Film Noir, 247-250. 
${ }^{16}$ Note for background the discussions in David E. Ruth, Inventing the Public Enemy: The Gangster in American Culture, 1918-1934 (Chicago 1996); Robert Warshow, "The Gangster as Tragic Hero," in Warshow, The Immediate Experience: Movies, Comics, Theatre and Other Aspects of Popular Culture (New York 1962), 83-88; George Grella, "The Gangster Novel: The Urban Pastoral," in David Madden, ed., Tough Guy Writers of the Thirties (Carbondale, Il. 1968), 186-198.

${ }^{17}$ Peter Biskind, "'They Live by Night' by Daylight," Sight and Sound, 45 (Autumn 1976), 218-22.

${ }^{18}$ See the readings provided by Ken Worpole, Dockers and Detectives: Popular Reading/Popular Writing (London 1983); Ernest Mandel, Delightful Murder: A Social History of the Crime Story (London 1984); Madden, ed., Tough Guy Writers; and, albeit in less overt political terms, Frank Krutnik, In a Lonely Street: Film Noir, Genre, Masculinity (London 1991). For a recent gay reading of film noir see the fascinating set of arguments in Robert J. Corber, Homosexuality in Cold War America: Resistance and the Crisis of Masculinity (Durham, N.C. 1997), 23-104.

${ }^{19}$ See Alfred Appel, Jr., "The Director: Fritz Lang's American Nightmare," Film Comment, 10 (November-December 1974), 12-17.

${ }^{20}$ Richard Lippe, "At the Margins of Film Noir: Preminger's Angel Face," in Silver and Ursini, eds., Film Noir, 161-176.

${ }^{21}$ On Hammett see William F. Nolan, Hammett: A Life at the Edge (New York 1983); Diane Johnson, Dashiell Hammett: A Life (New York 1983); Robert I. Edenbaum, "The Poetics of the Private-Eye: The Novels of Dashiell Hammett," in Madden, ed., Tough Guy Writers, 80-103.

${ }^{22}$ For commentary on the German contribution and the hard-boiled style to noir see Paul Schrader, "Notes on Film Noir," in Silver and Ursini, eds., Film Noir, 55-56. On The Maltese Falcon see Irving Malin, "Focus on 'The Maltese Falcon': The Metaphysical Falcon," in Madden, ed., Tough Guy Writers, 104-109. An introduction to crime fiction, which structured some of the aesthetics of noir, is found in Jerry Palmer, Thrillers: Genesis and Structure of a Popular Genre (London 1978); Palmer, Potboilers: Methods, Concepts, and Case Studies in Popular Fiction (London 1991).

${ }^{23}$ As an introduction to noir and Los Angeles see the breathtaking argument in Davis, City of Quartz, 36-46.

${ }^{24}$ Carl Richardson, Autopsy: An Element of Realism in Film Noir (Metuchen, N.J. 1992), 183.

${ }^{25}$ On the importance of Cain see Joyce Carol Oates, "Man Under Sentence of Death: The Novels of James M. Cain," in Madden, ed., Tough Guy Writers, 110-128.

${ }^{26}$ See Thomas Sturak, "Horace McCoy's Objective Lyricism," in Madden, ed., Tough Guy Writers, 137-162.

${ }^{27}$ Denning, The Cultural Front, 183.

${ }^{28}$ On Chandler see Fredric Jameson, “The Synoptic Chandler," in Copjec, ed., Shades of Noir, 33-56; Herbert Ruhm, "Raymond Chandler: From Bloomsbury to the Jungle - and Beyond," in Madden, ed., Tough Guy Writers, 171-185; and Fred Pfeil, White Guys: Studies in Postmodern Domination and Difference (London 1995), 105-166. For statements on noir and urbanism see David Reid and Jayne L. Walker, "Strange Pursuit: Cornell Woolrich and the Abandoned City of the Forties," in Copjec, ed., Shades of Noir, 57-96; Nicholas Christopher, Somewhere in the Night: Film Noir and the American City (New York 1997). 


\section{Left History 5.2}

${ }^{29}$ Frank McShane, The Life of Raymond Chandler (London 1976), 1.

${ }^{30}$ For a rather benign view see Deborah Thomas, "Psychoanalysis and Film Noir," in Ian Cameron, ed., The Movie Book of Film Noir (London 1992), 71-87.

31 C.L.R. James, American Civilization, ed., Anna Grimshaw and Keith Hart (Cambridge 1993), 121, 127, quoted in Robert J. Corber, Homosexuality in Cold War America: Resistance and the Crisis of Maculinity (Durham, N.C. 1997), 27-28.

${ }^{32}$ See the discussion of L.A. noir in Norman M. Klein, The History of Forgetting: Los Angeles and the Erasure of Memory (London 1997), 73-93.

${ }^{33}$ Comment on Himes, whose other work focussed on Harlem, can be found in Manthia Diawara, "Noir by Noirs: Towards a New Realism in Black Cinema," in Copjec, ed., Shades of Noir, 261-278; Fred Pfeil, "Policiers Noirs," in Pfeil, Another Tale to Tell: Politics \& Narrative in Postmodern Culture (London 1990), 64-68; Denning, The Cultural Front, 221, 227-228, 252, 257, 447-449. See, as well, Chester Himes, My Life of Absurdity: The Later Years (New York 1976). Note the argument in Eric Lott, "The Whiteness of Film Noir," in Mike Hill, ed., Whiteness: A Critical Reader (New York 1996), 81-101.

${ }^{34}$ Philip Durham, Down These Mean Streets a Man Must Go: Raymond Chandler's Knight (Chapel Hill, N.C. 1963), 76-77.

${ }^{35}$ Raymond Chandler, The Big Sleep [1939] (New York 1976), 215-216.

${ }^{36}$ See James Ellroy, My Dark Places (New York 1997).

${ }^{37}$ Raymond Borde and Etienne Chaumeton, "Towards a Definition of Film Noir," in Silver and Ursini, eds., Film Noir, 25.

${ }^{38}$ Cook quoted in Nicholas Christopher, Somewhere in the Night: Film Noir and the American City (New York 1997), 49-50.

${ }^{39}$ See the discussion in George Lipsitz, Rainbow at Midnight: Labor and Culture in the 1940s (Urbana, Il. 1994), 279-302; and the introduction J.P. Telotte, "Noir Narration," in Telotte, Voices in the Dark: The Narrative Patterns of Film Noir (Urbana, Il. 1989), 1-39.

${ }^{40}$ See Frank Krutnik, In a Lonely Street: Film Noir, Genre, Masculinity (London 1991), 21.

${ }^{41}$ Alain Silver and Elizabeth Ward, eds., Film Noir: An Encyclopedic Reference to the American Style (Woodstock, N.Y. 1979), 204.

${ }^{42}$ For another reading of space see Joan Copjec, "The Phenomenal Nonphenomenal: Private Space in Film Noir," in Copjec, ed., Shades of Noir, 167-198.

${ }^{43}$ For Cobb see Navasky, Naming Names, 268-273.

${ }^{44}$ Consider the statements on styles and motifs in noir film in Janey Place and Lowell Peterson, "Some Visual Motifs of Film Noir," and Robert Porfirio, "No Way Out: Existential Motifs in the Film Noir," both in Silver and Ursini, eds., Film Noir, 65-94.

${ }^{45}$ For guides to noir film see the abbreviated and much criticized statement, Raymond Durgnat, "Paint it Black: The Family Tree of Film Noir," in Silver and Ursini, eds., Film Noir, 37-52; and the more extensive compendium presented in Silver and Ward, Film Noir. Snapshot depictions of particular films appear in Barry Gifford, Devil Thumbs a Ride \& Other Unforgettable Films (New York 1988).

${ }^{46}$ Frances Farmer was a left actress who worked with the Group Theatre in the 1930s and had modest success in Hollywood before being incarcerated in a mental asylum in the 1940s. For a fictional account see Gordon DeMarco, The Canvas Prison (San Francisco 1982), while her life is memorialized in the 1982 film, Frances, starring Jessica Lange. 
${ }^{47}$ See Lipsitz, Rainbow at Midnight, 291.

${ }^{48}$ Dassin was indeed a communist, albeit one rather loosely affiliated with the Party. On Dassin see McGilligan and Buhle, eds., Tender Comrades, esp. 199-224. This collection of interviews with blacklisted Hollywood figures also contains extensive reference to the much-despised Dmytryk.

${ }^{49}$ Commentary on Night and the City appears in Glenn Erickson, "Expressionist Doom in Night in the City," in Silver and Ursini, eds., Film Noir, 203-207; Nicholas Christopher, Somewhere in the Night: Film Noir and the American City (New York 1997), 75-84.

${ }^{50}$ Wrestling as spectacle and its relationship to noir is touched on briefly in Christopher, Somewhere in the Night, 81-83, while I have drawn on the particular anlaysis in Roland Barthes, "The World of Wrestling," in Barthes, Mythologies (London 1983), 15-25. Sec for a more general statement on spectacle, Guy Debord, Comments on the Society of the Spectacle (London 1990).

${ }^{51}$ Davis, City of Quartz, 38.

52 Note the discussion in Charles Shapiro, "Nightmare Alley': Geeks, Cons, Tips, and Marks," in Madden, ed., Tough Guy Writers, 218-223.

${ }^{53}$ See, for instance, Palmer, Hollywood's Dark Cinema, 139-166; Hollinger, "Film Noir, Voice-Over, and the Femme Fatale," in Silver and Ursini, eds., Film Noir, 243258.

54 Janey Place, "Women in Film Noir," in Kaplan, ed., Women in Film Noir, 35-54.

${ }^{55}$ Lipsitz, Rainbow at Midnight, 296-297.

${ }^{56}$ See the DeMarco trilogy: October Heat (1979); The Canvas Prison (1982); and Frisco Blues (1985).

${ }^{57}$ Among many possible commentaries note Fred Pfeil, "Home Fires Burning: Family Noir in Blue Velvet and Terminator 2," in Copjec, ed., Shades of Noir, 227-260; Fredric Jameson, Postmodernism; or the Cultural Logic of Late Capitalism (Durham, N.C. 1991), 19-20, 279-296; Edward Gallafent, "Echo Park: Film Noir in the 'Seventies," and Leighton Grist, "Moving Targets and Black Widows: Film Noir in Modern Hollywood," both in Cameron, ed., Movie Book of Film Noir, 254-285.

${ }^{58}$ See, for instance, Jeremy G. Butler, "Miami Vice, the Legacy of Film Noir," and James Ursini, "Angst at Sixty Fields per Second," both in Silver and Ursini, eds., Film Noir, 289-306, 275-287.

${ }^{59}$ See Robert Polito, Savage Art: A Biography of Jim Thompson (New York 1995).

${ }^{60}$ Note Robert G. Porfirio, "The Dark Age of American Film: A Study of the American Film Noir," PhD dissertation, Princeton, 1979; Todd Erickson, "Movement Becomes Genre," in Silver and Ursini, eds., Film Noir, 307-330.

${ }^{61}$ Among the important, and differing, statements on women and noir, see Karen Hollinger, "Film Noir, Voice-over, and the Femme Fatale," in Silver and Ursini, eds., Film Noir, 243-360; Elizabeth Cowie, "Film Noir and Women," in Copjec, ed., Shades of Noir, 121-166; R. Barton Palmer, Hollywood's Dark Cinema: The American Film Noir (New York 1994), 139-168; and the essays in E. Ann Kaplan, ed., Women and Film Noir.

${ }^{62}$ On this background see Gregory D. Black, Hollywood Censored: Morality Codes, Catholics, and the Movies (Cambridge 1994).

${ }^{63}$ Andrew Vachss's writings include Flood (1985); Strega (1987); Blue Belle (1988); Hard Candy (1989); Blossom (1990); Sacrifice (1991); Shella (1993); Born Bad (1994); Down in the Zero (1994); Batman: The Ultimate Evil (1995); Footsteps of the Hawk 


\section{Left History 5.2}

(1995); False Allegations (1996); and Another Chance to Get it Right: A Children's Book for Adults (1995). For commentary see Gary Dretzka, "Disturbed avenger: Seeking evil with Andrew Vachss' urban vigilante," Chicago Tribune, 11 June 1989; Paul Mann, “A Heart and a Fist," Saturday Review in Vancouver Sun, 1 June 1991.

${ }^{64}$ Obviously I do not agree with the uitimatist ideological posturing of Fukuyama's understanding that the implosion of the Soviet Union in 1989 resolved the global confrontation of communism and capitalism in the latter's rightful and unambiguous favor, thus homogenizing the future of politics in an 'end of history.' The crisis of capitalist restoration in the once-Soviet Union, unfolding with terrifying rapidity over the course of the 1990s, confirms the banality of any 'end of history' posturing. Nevertheless, the cultural impact of this process is singularly important, especially in the capitalist west, as the evolution of noir suggests. For the original Fukuyama statement see Francis Fukuyma, "The End of History," The National Interest, 16 (Summer 1989), 3-18, and the more complex elaborations in Fukuyama, The End of History and the Last Man (1992). Significant readings of the problems posed in Fukuyama include Joseph McCarney, "Shaping Ends: Reflections on Fukuyama," New Left Review, 202 (November-December 1992), 37-54; Perry Anderson, "The Ends of History," in Anderson, A Zone of Engagement (New York 1992), 279-375. 